\author{
Piotr Hałaj \\ mgr \\ Katolicki Uniwersytet Lubelski Jana Pawła II \\ Wydział Prawa, Prawa Kanonicznego i Administracji \\ piotrhalaj91@gmail.com
}

DOI: 10.35117/A_ENG_20_04_03

\title{
Purchase and registration of a vintage car in the Polish legal system
}

\begin{abstract}
The scientific article is about vintage vehicles in the Polish legal system. The article mainly shows the lack of a precise definition of a historic vehicle in any of the legal acts. Moreover it shows how to buy such a vehicle, the advantages and disadvantages of owning it. The second part of the article only describes the procedure for registering a historic vehicle. In practice, this is a different process than for other cars. In Poland, it is recognized as expensive, time-consuming and complicated, which in many cases is effective as a warning to owners of vehicles qualifying as historic.
\end{abstract}

Keywords: Vintage Car; Historic Vehicle; Registration

\section{Introduction}

For several years in Poland, interest in old cars has been growing steadily. There is a growing group of people interested in both "oldtimers" and "youngtimers" ("Oldtimers" - usually these are vehicles over 50 years old. "Youngtimer" - vehicles produced in the second half of the 20th century) [1]. It is closely related to deepening the culture of society by striving to preserve and keep mementos from the past. The purchase of a vintage car allows the buyer to join the ranks of the elite group of historic automotive users, who therefore use the old technology and appreciate the style of previous eras. Increasingly, cars are bought for pleasure, in order to pursue one's own hobby. The owner, who has a modern car for traveling from point "A" to point "B", buys a second car - a vintage car for occasional weekend rides and participation in raids or rallies of this type of vehicles.

In addition to reaping the benefits of using them, many owners see them as a good capital investment. Due to the fact that there will be no more such cars, their prices are constantly growing, making it an alternative form of investment. There is a continuous increase in interest in historical and classic brands. Some, on the other hand, are still undervalued but forecast profits in the range of $30-40 \%$ per year [2]. Historic Automobile Group International entity dealing with studying the price changes of classic cars estimates the increase in their interest by $6.5 \%$ per year [3]. There are still many older vehicles on Polish roads. Currently, the possibilities of the Polish automotive market and the current law are conducive to the purchase of cars eligible for registration as historic. It is enough to mention at this point popular cars from the beginning of the 1990s, such as Audi 80, BMW 3 or 5 series, Fiat 126p, Polonez, Opel Kadett, Toyota Corolla or Volkswagen Golf. These cars, often from Polish showrooms or imported from abroad, are replaced every year with newer models, thus displacing the older generations from general use.

The purpose of this article is to analyze the current legal status related to the assignment of vehicles as historic vehicles and the related privileges and restrictions.

The first part of the article defines the concept of a historic vehicle, which is not entirely precise and raises many doubts, as well as the features that qualify the vehicle as a historic vehicle. In addition, one of the ways to re-register a deregistered car was indicated, as well as the privilege in the form of short-term insurance. The author also introduced the 
insufficiently explained by the legislator the issue of carrying out a gainful activity using a historic vehicle and the limitation of the owner's subjective right when selling the vehicle abroad.

The second part of the article presents the necessary documents for registering a vintage vehicle. The author focused mainly on the comprehensive explanation of the procedure for obtaining the status of a historic vehicle.

The subject of this article is dispersed among various legal acts, such as the Road Traffic Act of June 20, 1997, the Act on the protection of monuments and the care of monuments of July 23, 2003, the Act on compulsory insurance, the Insurance Guarantee Fund, and the Polish Insurers' Bureau. Communication of May 22, 2003, Act on Road Transport of September 6, 2001, Act on Recycling of End-of-Life Vehicles of January 20, 2005. The so-called The Turin Card providing information on the use, maintenance, and restoration of such vehicles. It is worth emphasizing that many of the premises relating to the registration of a historic vehicle in the Polish legal system are discretionary, and decisions in these matters are made in the conditions of a large administrative gap by applying vague concepts.

\section{Methods of acquiring a historic vehicle}

The Polish vintage car market has experienced a significant increase in interest in recent years. There are more and more enthusiasts and enthusiasts of the old motorization, who unite in clubs and associations. Such a large interest increases the demand, which raises prices, which in turn causes the creation of commission shops or companies specializing in the sale of vintage cars [4].

Due to the unflagging popularity of vintage vehicles, the current automotive market offers a large variety of models in various price ranges without clearly indicating its upper limit. A potential buyer when looking for a "youngtimer" or an "oldtimer" should make his choice, by specifying the age range of the vehicle, its technical condition, body version, and above all, the upper price limit that it is willing to pay to become its owner.

When searching for a vintage car, one should start with online resources. Well-known auction portals such as www.allegro.pl, apart from passenger cars, delivery vans, trucks, and buses, also offer vintage cars. Advertisements can also be found on internet forums associating enthusiasts of the old automotive industry. In addition, there are also websites specializing in the sale of items exclusively on historic topics, e.g. www.alleretro.pl, as well as those that are aimed only at the sale of vintage vehicles such as "youngtimers" and "oldtimers". These are websites such as: http://www.gieldaklasykow.pl/, http://youngtimermarket.com/ and http://prlauto.pl/, which offer a wide range of models with a detailed description and photo report. Sometimes, however, it is also worth following normal ads, because not all sellers classify their cars as "classic".

Classic car sales offers can also be found in a special automotive press. At press stands, among the magazines offering an overview of advertisements of this nature, there are, among others such titles as Automobilista and Classicauto. This type of press, in addition to articles containing tests, advice, and descriptions of specific models, also has special advertising sections, where both private individuals and entrepreneurs publish offers for the sale of parts, performance of renovation services and surveying services.

Another frequently used method of purchasing a "classic" is participation in various types of meetings, raids, rallies, or exhibitions of vintage vehicles. During such events, it is possible to view a given model, and sometimes to conduct a personal conversation with the owner, which may result in a transaction (photo $\mathbf{1}$ ). 


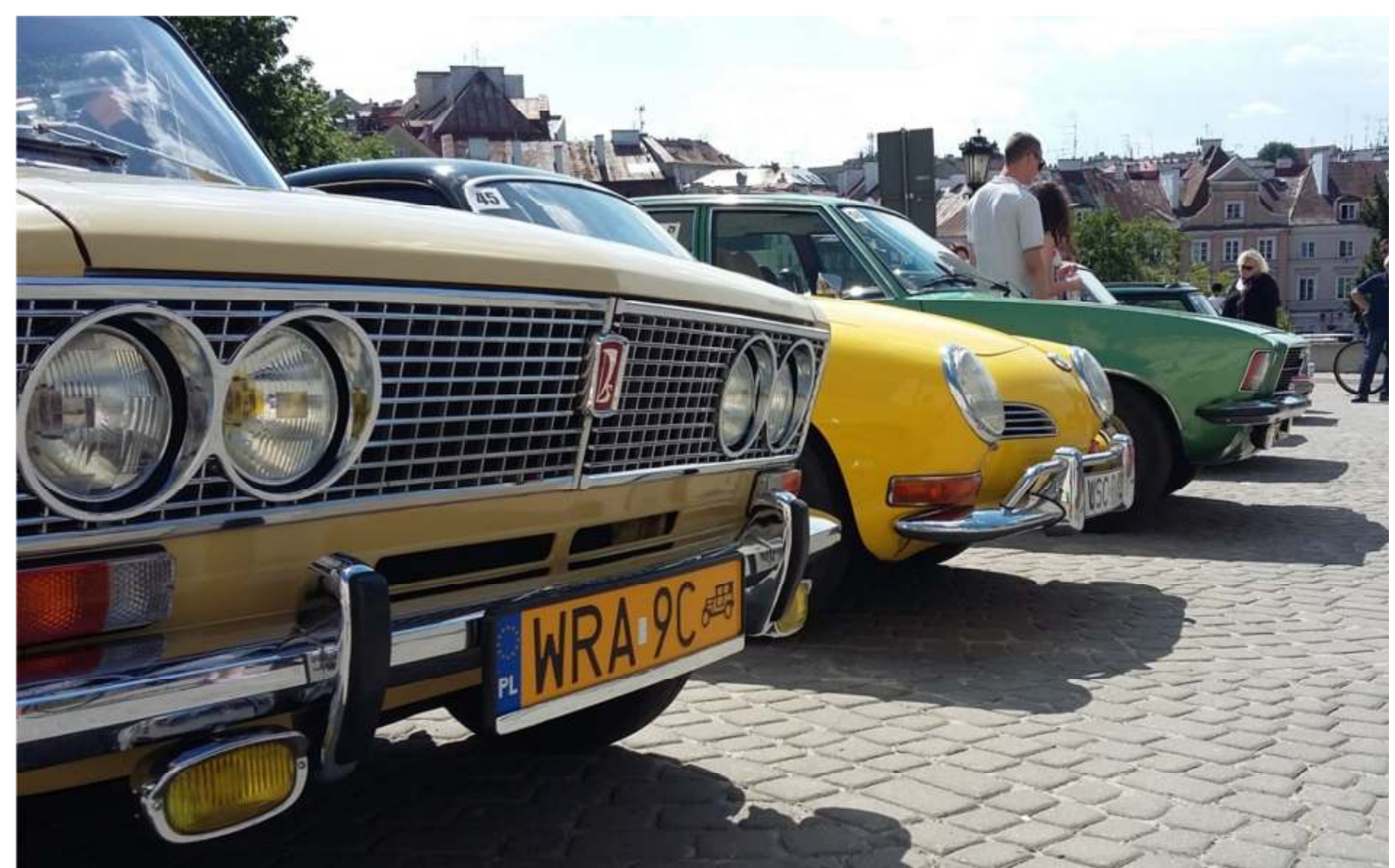

1. Summer exhibition of vintage cars at the Lublin Castle - Piotr Hałaj (own photo).

A good place to buy a historic car in an unfinished or restored state, as well as the necessary parts, are trade and exhibition exchanges visited by collectors or hobbyists of monuments. In Poland, the most popular stock exchange of this type, organized in Łódź since 1992, is Moto Weteran Bazar. The meetings held periodically (4 times a year) attract interested people because during their duration it is easy to get valuable information and advice, as well as buy, sell or replace everything related to the historic topic [5].

Still, the least used way of acquiring a classic car is through the auction house. Currently, the only commercial company of this type in Poland is Ardor Auctions (in Poland it is still a not very popular way to buy a vintage car, aimed mainly at wealthy customers. More information about this auction house can be found on the website: https://www.ardorauctions.pl/) [6].

The places where purchases can be made are also car dealerships and car showrooms selling vintage cars. Their offer usually includes imported cars that have already undergone a comprehensive renovation, thanks to which their condition is perfect. This offer is largely addressed to the wealthy [7].

You can also consider purchasing a vintage vehicle abroad. The foreign automotive market may have in its resources not only rare models, unavailable in Poland but also very popular ones in better visual and technical condition. Assistance in finding such offers, as well as buying and bringing a car to Poland is provided by various companies, e.g. Auto - Camp.pl, Autodal Import or fabrykaklasykow.eu.

In conclusion, the conditions that are known when buying a traditional car do not translate into the conditions that occur when buying a vintage car. A frequent practice when browsing contemporary car offers is to take into account the mileage of the vehicle - the lower the better. In the case of vintage cars, it is a secondary matter, taking into account the uniqueness of a given model and the related possibilities of supplying parts leading to its complete reconstruction. When deciding on such a purchase, it is also worth remembering that there is no certainty that the purchased vehicle will be registered and put into service, and will 
gain in value over time.

\section{Definition of a historic vehicle}

The monument is widely recognized as an element of human cultural heritage, a testimony to his activity, identifying a political, historical, and cultural society. According to Art. 3 clause 1 of the Act of 23 July 2003 on the protection of monuments and the care of monuments, it is real estate or movable property, parts or complexes thereof, being the work of a human being or related to his activity and representing a bygone era or events, the preservation of which is in the public interest due to for its historical, artistic or scientific value [8].

The first references to the definition of a historic vehicle were introduced in 1997 in the Road Traffic Act. An attempt to refine the definition was made in 1999 by the Polish Motor Association by joining the International Federation of Historic Vehicles (FIVA in French) representing such vehicles on the international arena. This definition was included in the FIVA International Technical Code, the current version of 2011 of which indicates that it is a mechanically driven road vehicle, at least 30 years old, preserved and kept in a historically correct condition, which is not used as a means of everyday transport, part of our technical and cultural heritage [9].

The normative definition is contained in Art. 2 point 39 of the Road Traffic Act. According to its content, a historic vehicle is a vehicle that, on the basis of separate regulations, has been entered in the register of monuments or is in the provincial register of monuments, as well as a vehicle entered in the inventory of museum objects, in accordance with separate regulations [10]. This definition is supplemented by the Act on the Protection and Guardianship of Monuments [11] and the Act on Museums [12] by clarifying the collections in which they are saved. Thus, on the basis of the first one, it should be understood that the basic, special protection covers those objects included in the general national register of monuments, while those located in a given voivodeship - in the voivodeship register of monuments (the content of the data in these collections is specified in detail in: Of the Minister of Culture and National Heritage on the keeping of a register of monuments, national, provincial and municipal register of monuments and the national list of stolen or unlawfully exported monuments from 26 May 2011 (Journal of Laws 2011 No. 113 item 661) [13]. Despite the independence of both registers, the presence in at least one of them creates additional obligations for the owner or holder of a monument in caring for it. Based on Article. 28 of the first of the above-mentioned acts, in the event of damage, destruction, loss, theft, a threat to the monument, change of the place of storage of the monument, and change in its legal status, the provincial conservator of monuments should be notified within the prescribed period. In the absence of such notification, a fine is imposed in the amount of PLN 500 to PLN 2,000 (Article 107a of the Act on the protection and care of monuments). The Act on museums, in turn, provides for the possibility of entering into the inventory of museum objects, which is one of the forms of registering monuments in museums, at the same time emphasizing the essence of shaping social and public interest by clearly indicating that these are national goods.

The act on the protection of monuments and the care of monuments first defines the concept of a monument. Art. 3 point 1 of this Act describes a monument as "real estate or a movable thing, their parts or complexes, being the work of man or related to his activity and representing a bygone era, or an event whose preservation is in the public interest due to the possession of historical, artistic or scientific value '. The definition given in this way shapes not only the scope, but also the subject of protected objects, and especially emphasizes the individual features that a monument should have. The clarification of this definition is provided in Art. 6 sec. 1 point 2 letter d of the above act. According to it, a monument is a 
product of technology, especially devices, means of transport, as well as machines and tools testifying to material culture, characteristic of old and new forms of economy, documenting the level of science and civilization development. Despite the existence of a definition of a historic vehicle, the legislator does not define it directly. In a way, Art. $51 \mathrm{sec} .1$ point 14, by listing the category of monuments requiring a one-time export permit, also mentions a historic vehicle, treating it as a means of transport that is more than 50 years old and its value is higher than PLN 32,000.

In conclusion, by definition, anyone interested in this subject would first refer to the content of this act in order to search for a definition of a historic vehicle. In fact, however, despite the existence of a definition of a movable monument, the legislator does not provide a definition of a historic vehicle, thus causing consternation in the recipient.

The most frequently used definition of a historic vehicle, but significantly different from the others, is described in the Act of May 22, 2003, on compulsory insurance, the Insurance Guarantee Fund, and the Polish Motor Insurers' Bureau [14]. This act introduces a de facto new concept of "historic vehicle", which includes the concept of "historic vehicle". Necessary to qualify a vehicle as a historical vehicle seems to require the vehicle to be a motor vehicle. The remaining issues were differentiated due to: the historic nature of the vehicle within the meaning of the Road Traffic Act, the age of at least 40 and both the age of at least 25 and the uniqueness or particular importance of documenting the automotive history of a given vehicle.

However, the above-mentioned definitions have nothing to do with reality. In practice, these regulations are not applied by the Provincial Monument Conservator. None of the acts specifies precisely the specific requirements that are currently commonly found in internet sources. However, it has become a norm that Monument Conservators adopt 3 main requirements qualifying a given vehicle as a historic one, such as age at least 25 years, no production of a given model for 15 years and at least $75 \%$ of original parts (the indicated requirements were included in the letter of the National Director Of the Center for Research and Documentation of Monuments to Provincial Conservators of Monuments of 13 January 2004) [15]. The situation is further complicated by the fact that in some cases it is possible to register despite the failure to meet the age requirement. This applies to vehicles that are unique due to the design or technical solutions used in them, as well as their use by a famous person, e.g. a politician, actor, athlete, or clergyman (pope) [16].

The basic requirement for registering a historic vehicle in most cases is the age requirement. Nowadays, many cars from the beginning of the 90s are beginning to fulfill this basic condition. It seems that the need to eliminate old-style (tuned) styled cars created the need to specify the age criterion through the originality criterion. Although the age of a historic vehicle seems to be the most important, it is a compromise to this rule. This derogation is based on the fact that it is the numerical value of $75 \%$ of the original part that may determine the historic character of the vehicle. It follows that cars should first of all have the original engine, suspension and bodywork to meet the criterion [17]. After a careful analysis of the Act on the Protection of Monuments and the Guardianship of Monuments, no provision of this Act indicates this requirement. Moreover, cars after modifications of elements determining their originality do not meet the requirements qualifying the vehicle as a historic one [18]. In turn, the consumables, among others tires, battery, seals, windows do not have to be original [19]. After the renovation, it is important that the car corresponds to the original pattern in $75 \%$ of the originality of the parts so that the end result resembles the initial state. It will be difficult for the expert to determine the percentage of original parts, so the main emphasis, in this case, is that the car simply resembles the original that left the factory. Replaced parts should be manufactured to resemble the authentic ones. Practice shows that 
even when about $80 \%$ of the parts are replaced, the conservator may recognize the car as original (photo 2 ).

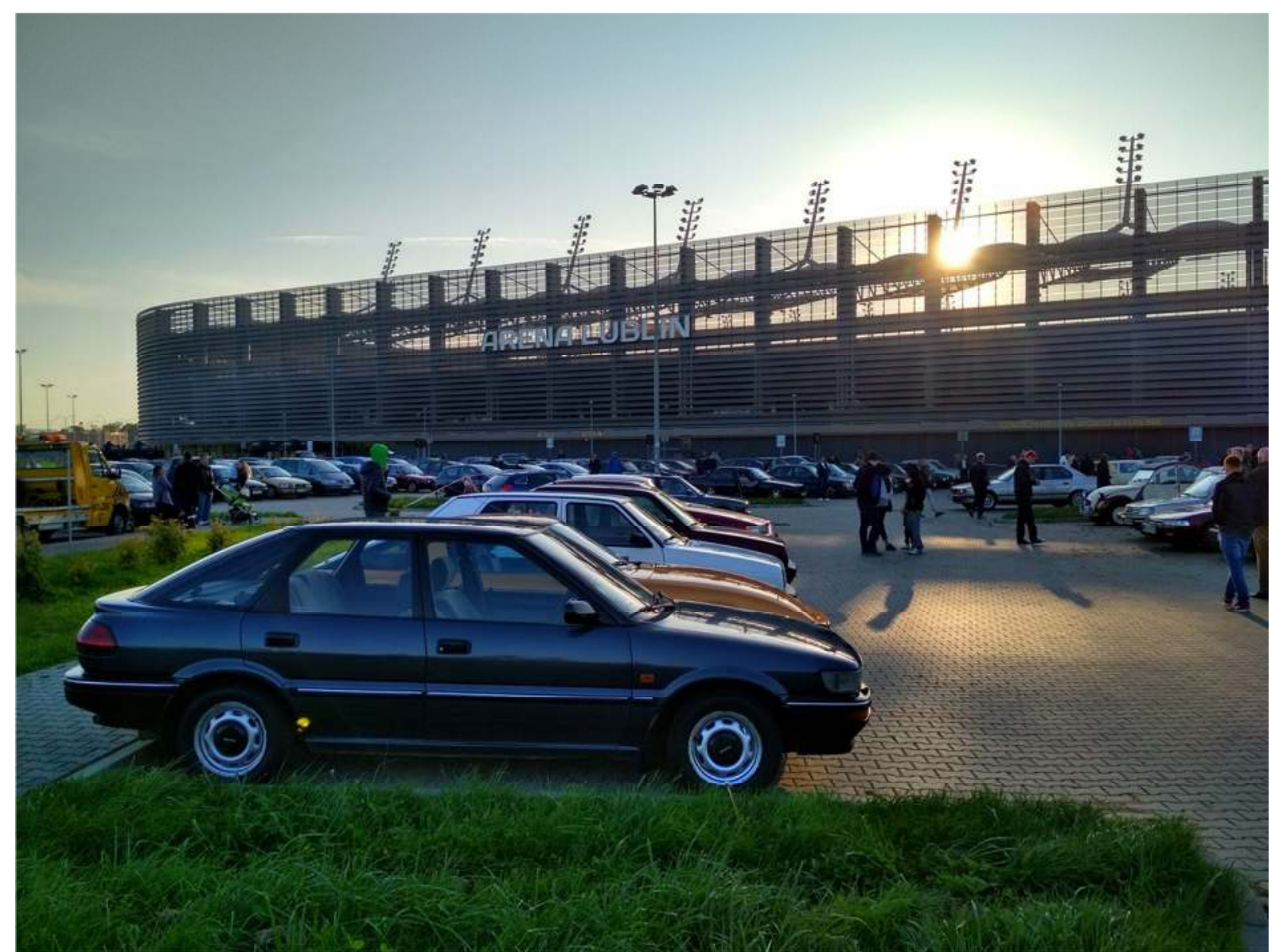

2. Autumn rally of "Lubelskie Classics at Night "at the city football stadium in Lublin - Piotr Hałaj (own photo).

The owner of the vehicle is obliged to maintain a high degree of originality, even after entry in both the register and the museum inventory. Failure to comply with this requirement may result in deletion from the register (art. 13 of the Act on the protection and care of monuments). The legislator made the loss of the status of a monument conditional upon its destruction, but to such an extent that it would lose its historical, artistic, or scientific value. In practice, it is difficult to define and gives great freedom in the assessment of monument conservators. A clarification of the act, especially in technical and procedural matters, is the Regulation of the Minister of Culture and National Heritage of 26 May 2011 on keeping a register of monuments, national, provincial and communal records of monuments and the national list of stolen or illegally exported monuments [20]. Therefore, it is difficult to estimate whether a given vehicle has been "damaged" to the extent that it loses the values mentioned above, and thus obtained less than $75 \%$ of its originality. It makes this requirement a "lex imperfecta" mainly due to the lack of a control procedure in this matter. The requirement of originality should be constantly met and verifiable just before the vehicle is registered. When using it, the owner, by making certain modifications, is not obliged to report it to any authority, thus no one can say that the converted vehicle has less than $75 \%$ of the original parts and therefore should be removed from the register.

The practices of some Monument Conservators are controversial among owners of vintage cars. An example of such practices is the Lublin Conservator of Monuments, which, 
in reference to the Insurance Act, refuses to enter in the register of popular vehicles or vehicles that are at least 25 years old and meet the criterion of uniqueness. Entry in the register may take place after meeting the statutory, historical and technical conditions and, exceptionally, the production quantity [21]. It seems that the last criterion means that the records include, in particular, single copies of individual models that meet the age requirements. As a rule, this is contrary to the idea of monument protection and is unfair to the owners of popular large-scale models.

Theoretically, a historic vehicle is associated with a gasoline-powered vehicle, however, cars equipped with an LPG installation can also be monuments. This applies primarily to "youngtimers", which at the beginning of the $90 \mathrm{~s}$ were equipped by manufacturers with this type of fuel as standard for powering vehicles [22]. This is a rather problematic issue because historic cars have an indefinite inspection, and if they have an LPG installation, the road law indicates that the tests should be carried out annually (Article 81 (4) of the Road Traffic Act indicates that vehicles with installed a technical device subject to technical supervision) [23]. This issue is clarified by the Regulation of the Minister of Infrastructure of 31 December 2002 on the technical conditions of vehicles and the scope of their necessary equipment [24], namely Annex 9 to this regulation. It indicates additional conditions describing the efficiency of the technical device fueled by the gas of the vehicle, including $\S 4$ sec. 1 , the need to meet the conditions specified by the technical supervision was clearly emphasized. In addition, in the Regulation of the Minister of Transport, Construction and Maritime Economy of 10 May 2013 on the approval of the method of assembly of an installation adapting a given type of vehicle to gas supply [25], the parameters enabling its legalization were described, so that the documentation could provide a record confirming its correctness and safety. functioning.

Historic vehicles as a special group of vehicles are not covered by modern parameters in terms of construction and equipment, as evidenced by the content of $\S 1$ of the Regulation of the Minister of Infrastructure of December 31, 2002, on the technical conditions of vehicles and the scope of their necessary equipment. This exception is confirmed by Art. $66 \mathrm{sec} .1 \mathrm{~b}$ point 2 of the road law. This means that it does not have to meet the current technical requirements, i.e. there is no obligation to have, among others indicators or seat belts, and sometimes may be equipped with improper lighting or protruding parts. The vehicle is primarily subject to the technical requirements in force on the day it leaves the factory [26]. In addition, owners of special-purpose vintage vehicles, such as ambulances or fire trucks, are not required to dismantle sound and light signals. Only their use on the public road was forbidden (Art. 66 (4a) of the Road Traffic Act).

Previous generations of vehicles are being replaced by newer and newer generations. Some of them find new owners, while others are often scrapped. Polish law clearly indicates that the junkyard is the "last stage of life" of the vehicle (Art. 79 (4) of the Road Traffic Law) [27] ". There is an exception to this general rule, inter alia, for the vehicles covered in this article. This is confirmed by the provisions of the Act of January 20, 2005, on the recycling of end-of-life vehicles, namely art. 2 clause 2 [28], where the legislator emphasized that its regulations do not apply to historic vehicles. In addition, the Road Traffic Law (also known as the Highway Code) also provides protection to such vehicles, i.e. historic vehicles and those at least 25 years old, recognized by a car expert as unique or of particular importance for documenting the history of the automotive industry (Article 79 (4) (2) and 3). This means that if a potential buyer becomes interested in a given vehicle that has been deregistered and parked in the scrapyard, it may return it to public roads after meeting certain requirements. For this purpose, first of all, an opinion of a car expert will be needed, which will confirm that a given vehicle is a cultural object that should not be destroyed by sending it to steel mills. 
Then there is the issue of buying the vehicle and issuing an invoice confirming the sale, and consequently its registration on white or yellow plates, depending on the owner's decision.

Owners of historic vehicles can count on a derogation in the scope of compulsory vehicle insurance, as opposed to drivers who own normal cars, registered in Poland. They must conclude an insurance contract, at least for a period of 12 months, which is confirmed by the Act of May 22, 2003, on compulsory insurance, the Insurance Guarantee Fund, and the Polish Bureau of Motor Insurers, namely art. 4 point 1 and art. 26 [29]. At the same time, the legislator in Art. 27 provided for an exception, among others for historical vehicles, i.e. historic vehicles in accordance with the Highway Code, vehicles at least 40 years old and vehicles at least 25 years old, which have been recognized by a car expert as unique or of particular importance for documenting the history of the automotive industry. Owners of such vehicles have the right to conclude a short-term civil liability insurance contract for a period shorter than 12 months, but not shorter than 30 days (Article 27 (1) and (5) of this Act). The provided exception is a privilege for owners of vintage vehicles. The possibility of short-term insurance allows not only savings but also the effective use of the insurance, thanks to which it is purchased before planned trips to various types of rallies, exhibitions, or raids, usually in the summer. During the wintertime, when the car is usually garaged and does not participate in traffic, it does not make sense for it to be covered by third-party liability insurance.

There are many insurance companies on the market, but few have historic vehicle liability insurance in their offer, and it is not easy to find offers with AC insurance (Autocasco). Until recently, one of the most advantageous offers of third party liability insurance was proposed by the PZU Insurance Company for years. Owners using its offer with no damage done could get up to $70 \%$ discount, regardless of whether the vehicle was actually registered as a historic monument. At the end of 2018, the insurer tightened the regulation, so that in order to benefit from the discount, the vehicle should first of all have the so-called "yellow plates" registration.

Currently, the most profitable insurance offer for "oldtimers" and "youngtimers" is offered by the Compensa Insurance Company - under the name of "OC MOTOKLASYKI". This offer is aimed at owners of vehicles with both standard and yellow number plates over the age of 25 . The range of discounts is up to $70 \%$, and with PZM membership, it increases by another $20 \%$ [30].

The issue of voluntary AC insurance is presented a bit differently. When choosing it, the owner may face many difficulties. Insurers are reluctant to offer this type of insurance, mainly due to the difficult assessment of the value of the vehicle, requiring the involvement of additional appraisers. As a result, there are no offers in the field of AC insurance or high unattractive premiums [31].

A historic car may be used for occasional transport (Article 18 (4b) of the Road Transport Act [32]). It is the transport of passengers, which is not regular transport, consisting in the public transport of passengers and their luggage. It is also not a special regular transport (non-public regular transport) and a shuttle service based on the multiple transport of organized groups on the same route (Article 3, points 7, 9, 10,11). For occasional transport, a vehicle designed for the transport of more than 7 people, including the driver, is used (Article 18 (4a)). In this case, however, such activity requires obtaining an appropriate license, which may also be granted to the entrepreneur (Article 5b (1) (2) in conjunction with Article 5c (1)). Moreover, the owner of such a vehicle is not entitled to an unlimited technical inspection, which is why he is obliged to carry it out every year (Article 81 (10) of the Road Traffic Law).

The legislator regulated the issue of occasional transport, but only in relation to vehicles structurally equipped with 7 or more seats. The issues of typical cars, e.g. 5 
passenger cars, were omitted unless it was Art. $18 \mathrm{sec} .4 \mathrm{~b}$ does not clearly authorize this type of activity. Pursuant to this provision, occasional services may also be performed by vehicles that do not meet the requirement of at least 7 seats and are the sole property of the entrepreneur or are the subject of leasing of the entrepreneur. In this case, the fate of the owners of cars used, for example, for wedding transport depends on the interpretation of the regulations by the Road Transport Inspection Inspectors, because for violation of this provision in Annex 3 to the Road Transport Act, a fine of PLN 8,000.00 is indicated.

In the next issue, the restriction of ownership rights should be presented. The Basic Law, which grants protection to a specific right held by an individual, also clearly indicates its limitations. Art. 64 sec. 3 of the Constitution of the Republic of Poland [33] sets out the framework for permissible restrictions in the case of property rights. These, as one of the most complete property rights, cannot take an absolute form, which is clearly emphasized by both Polish doctrine and jurisprudence [34]. Administrative protection instruments are to ensure such a system of protection and restrictions to keep the monument intact for future generations.

When deciding on a historic vehicle, one should be aware that additional obligations are acquired due to the possession of an item that is the cultural heritage of the nation. In this case, the free right to use and dispose of the thing may be exercised, but within the limits provided for by the law. Although the person who owns the monument does not have full authority to dispose of it, going abroad with him. For this purpose, he must obtain a permanent or temporary permit. The main purpose of issuing permits is to keep the monuments in the country and protect them against illegal export, which could lead to their loss of value or a change in their destination. The premise for taking the monument away is age and its value. Article 51 (1) 1 of the Act on the protection of monuments and the care of monuments clearly indicates that such a permit is necessary for the export of means of transport that are more than 50 years old and their value exceeds PLN 32,000. The matter is complicated by paragraph 4 of this article, which prohibits permanent exports abroad, e.g. monuments entered in the register or in the museum inventory. Pursuant to Article 2 (39) of the Highway Code, the definition of a historic vehicle is a vehicle entered in the register of monuments or in the provincial register of monuments, as well as a vehicle entered in the inventory of museum objects, in accordance with separate regulations. Therefore, if the vehicle is classified as a means of transport that meets the requirement of more than 50 years and the value exceeds PLN 32,000, and at the same time is not entered in the register of monuments or museum objects, it is possible to apply for a one-time permit for permanent export abroad.

The exception are, however, monuments brought from the territory of the EU to Poland for a period not longer than 3 years. They do not require a license, as long as the export is made to the territory of these countries (Article 59 (1) (4) of this Act).

A person who owns a monument, selling it abroad, may apply for a one-time permit for permanent export abroad, which is granted by the Minister for Culture and National Heritage. In a situation where a monument has a special value for cultural heritage, it may refuse to issue a permit. In order to obtain a permit, the owner of the vehicle must submit an application for it through the provincial inspector of monuments. From the moment of receiving the permit, the removal of the monument may take place within 12 months (art. 52 of the Act on the protection and care of monuments).

Pursuant to Art. $51 \mathrm{sec} .2$ of the act on the protection and care of monuments entered in the register or inventory of museum objects may be temporarily exported abroad, provided that their owners guarantee that it will not be destroyed or damaged and that it will be brought to the country before the expiry of the permit. 
When driving a historic vehicle abroad for utility, exhibition, or conservation work, you can apply to the provincial inspector of monuments for a one-time permit to temporarily transport the monument abroad. The term of this permit is 3 years from the date of its receipt (Article 53 of the Act on the protection and care of monuments).

In addition, it is also possible to obtain multiple individual permits for the temporary export of a monument abroad for utility or exhibition purposes. Such a permit is also issued by the voivodship conservator of monuments, and its validity is 3 years from the date of issue (Article 54 of the Act on the protection and care of monuments).

In all 3 cases, after submitting an appropriate application, the provincial conservator of monuments inspects the monument and sometimes may use the help of competent experts ( $\S$ 7 (1) and (2) of the Regulation of the Minister of Culture and National Heritage on the export of monuments abroad of April 18, 2011. (Journal of Laws 2011 No. 89 item 510 [35]).In the event of failure to comply with the above-mentioned provisions of the Act on the protection and care of monuments, persons exporting monuments are subject to criminal liability from 3 months to 5 years for their illegal export or exceeding the expiry date of the permit (Article 109 of this Act).).

The key point in the discussed issue is to have correct information on the age of the vehicle, its value and data on its presence in the register of monuments, provincial register of monuments or the inventory of museum objects on the basis of which the permit is issued. If the vehicle is a prototype or one of the few copies, the Minister for Culture and National Heritage will most likely issue a negative decision regarding a one-time permanent export of the monument abroad. Therefore, obtaining such a permit is a deliberate effort by the legislator, as it is intended to maintain monuments not only in good condition, but also in Polish cultural resources. On the other hand, the application of criminal liability in the given dimension is sufficiently motivating, thanks to which it fulfills its function.

\section{Registration procedure}

The process of registering a vintage car seems to be a complicated and costly procedure.

It basically consists of three steps. Sometimes, due to circumstances, there is an additional stage consisting in issuing an opinion about the vehicle by an expert in automotive technology (an expert in the field of historic vehicles). An opinion becomes necessary when the car is permanently deregistered or recovered from a junkyard. In practice, it is also an additional requirement applied by some restorers in the registration process.

The expert's opinion includes an assessment of whether the vehicle meets the criteria of a historic vehicle. On the other hand, professionally taken photos confirm this quality and are also useful for attachment in the following procedure. The expert's opinion consists of a descriptive part and a part with photos of the car subject to the opinion. In addition to confirming the description of the car, the photos are also an element of the vehicle registration card, therefore the method of making photographic documentation is governed by the guidelines relating to the content of the registration card. The entity authorized to prepare such an opinion is an expert recommended by the National Agreement of Automotive Experts, who by definition has professional knowledge in this field. Neither the legislator nor the organizations associating car experts have introduced the model of regulations for the preparation of opinions for judicial purposes and no mechanisms for determining the price of such an opinion. However, it should be remembered that the expert opinion in the car registration process plays a slightly different role than the opinions issued by experts in court proceedings. First, the appraiser issues an assessment judgment relating to the historic value. Secondly, the registration procedure is initiated at the request of the car owner, and the opinion is not an official document, but a private one. Only the cost of this service seems to 
be problematic. The price is not clearly defined, because there is no clearly indicated maximum and a minimum rate, which is why it is freely shaped according to the workload of experts. Moreover, both when the opinion is voluntary and obligatory, it does not guarantee entry. Even if this document is an obligatory attachment to the registration application, it does not guarantee a positive outcome.

Taking into account the circumstances presented above, the procedure begins with the submission of an application for entry in the register of movable monuments by the Provincial Conservator of Monuments. As it seems, an integral part of the application is the Technical Monument Registration Card, also known as the "white card" (the name of the white card comes from the color of the cardboard on which it was printed. The pattern was invented in the 20th century, at the same time specifying such details as thickness, color, stiffness, and size) [37]. The contemporary specimen of the card is made public by the National Heritage Institute (formerly known as the National Center for Research and Documentation of Monuments), which presents both the specimen of the card and a description of how to fill it in on its website [38]. The application is submitted on a special form (pursuant to Art. 63 of the Code of Administrative Procedure [39] - hereinafter referred to as KPA). The application for entry shall be accompanied by 3 copies of the Technical Monument Record Card. In addition to the formal requirements as to the content of the card, there are also requirements regarding the form of the card document. Only a document with a weight of $180-240 \mathrm{~g} / \mathrm{m} 2$ in A3 format, folded after printing to A4 format, can be accepted as a Technical Monument Record Card. The essence of the Technical Monument Record Card - identification by means of verbal description and photographic documentation of a movable monument. Therefore, the card must contain at least 1 photo. In addition, the photographic material supports the description. Inside, there should be at least 1 photo with a minimum size of $9 \times 13 \mathrm{~cm}$ on glossy photo paper. The photographic material is precisely described, and the photographs allow the identification of the object, showing its general appearance and important elements. If additional information is attached, which does not fit in the designated boxes, attachments (inserts) in the "Attachments" section should be made on paper with a grammage of 140 - 160 $\mathrm{g} / \mathrm{m} 2$. The card consists of 4 pages with 27 fields, which the author fills in by computer or machine, using concise and clear vocabulary together with special terminology from this field. Each of the 3 copies must be completed separately, except for the method by the socalled carbon paper (they cannot be photocopies). In the context of the requirements related to the resolution of an administrative case, the rules relating to the method of filling in the card are marked with unnecessary formalism and at the same time referring to archaic methods of filling in documents. Already at the stage of submitting the application for entry, correctly read formal requirements exclude the possibility of submitting an electronic application, as well as the recognition that the application is formally deficient in the use of a different card in relation to the historical record card of the monument, with different weight and format. It is true that the conditions relating to supplementing the card can be read in relation to Art. 63 $\S 3$ of the CAP, but this means that pursuant to Art. $64 \S 2$ of the CAP, e.g. the use of paper of a different grammage may be considered as a formal failure of the application, and the applicant will be requested to complete it. In the event of failure to comply with this instruction, the application will not be considered.

The formalism related to the requirements relating to the type of paper on which the Card can be printed is in a way correlated with the requirements relating to the content of the Card. The necessity to use terms that often reflect the factory condition means that this part of the application is actually completed by a person with specialist knowledge, on a paid basis. Naturally, these people include the previously appointed experts. This is another step in this procedure performed by a third party, payable and does not guarantee entry in the register. 
It seems that the evidentiary proceedings are conducted in relation to the content submitted in the application and the white card, which, however, does not preclude the authority from using the principle of objective truth (Art. 7 CAP), as long as this assumption is obvious and complies with the rule of law after all the content of the application and the white card is the responsibility of the applicant, not the appraiser. In the context of the provisions of the Code of Administrative Procedure relating to the taking of evidence, the obligation to submit an application with a white sheet should be assessed. A doubt arises here when the card is completed by an expert. In the application for registration, the author and the year in which the card was developed must be indicated. The regulations do not provide a basis for considering the expert to prepare an expert opinion/professional evaluation in the course of submitting the application, therefore only the owner/applicant is responsible for the final shape of the application. In accordance with the principle of free evaluation of evidence and the principle of equality, applications submitted and completed exclusively by the applicant, with the help of an expert, must be treated equally. The white card completed by the expert is not an official document. It is not even a private document completed by the applicant or a third party. It is only an attachment to the application. However, this fact can be assessed in the overall evidence, in the context that a possible refusal must take into account the fact that the characteristics of the vehicle were drawn up by a person with specialist knowledge and experience. Although the authority has the right to make its own assessment of the condition of uniqueness, it should be remembered that it is based on the content of the applications and the white card. For this reason, questioning the uniqueness of the vehicle with a different assessment of the content contained in the white card should be made taking into account the provisions of the evidentiary procedure, in particular art. 80 and $81 \mathrm{KPA}$. The authority may use the type of evidence that is adequate to the circumstances challenged in the application. It seems that in this situation when the card was supplemented by the appraiser, the authority questioning not so much the formal correctness as the material correctness of the content contained therein, should use the expert's opinion. To sum up, on the basis of the rules of evidence procedure contained in the CAP and the conditions for obtaining an entry, a refusal decision may only be dictated by the failure to meet any of the registration conditions, and the reasons for this refusal should be thoroughly justified. In particular, the authority should precisely explain how it understands in this particular procedure the fuzzy concepts that have occurred. The exact justification is all the more a requirement that determines the correctness of the decision when the author of the entries in the white card is an expert whose description is questioned by the conservator.

One copy of the finished white card goes to the Provincial Conservator of Monuments, the second to the National Heritage Institute, and the third goes to the owner [40].

The white card is an obligatory element of the free application for the inclusion of the vehicle in the register of monuments. The entry is made in accordance with the rules set out in the Code of Administrative Procedure and in the Act on the protection and care of monuments. According to Art. $35 \S 3$ of the CAP, the time limit for issuing a decision is 1 month.

The decision on entry in the register is a related decision, which means that the authority should make the entry if the conditions set out in the Act on Monuments are met. In practice, however, the registration procedure allows the authority to introduce elements of discretion in the decision. The concept of the uniqueness of a vehicle used in the Act as one of the premises of a historic vehicle is a blurred concept. The authority has the right and obligation to assess, on the basis of the content of the card and the application, whether the vehicle is unique, i.e. whether he introduced unique, unprecedented technical solutions, or documented important historical events. Recognizing a car as unique should be sufficient to 
meet this condition, while it is customary that this concept is additionally evaluated, e.g. indicating low or high uniqueness of the vehicle. Negative decisions are made based on the criterion of low vehicle uniqueness. It seems that this practice goes beyond the acceptable notion of uniqueness. Demonstrating that the decision was based on the so-called low uniqueness of the vehicle is the basis for an effective appeal or even an application for annulment of the decision due to a gross violation of the law (photo 3 ).

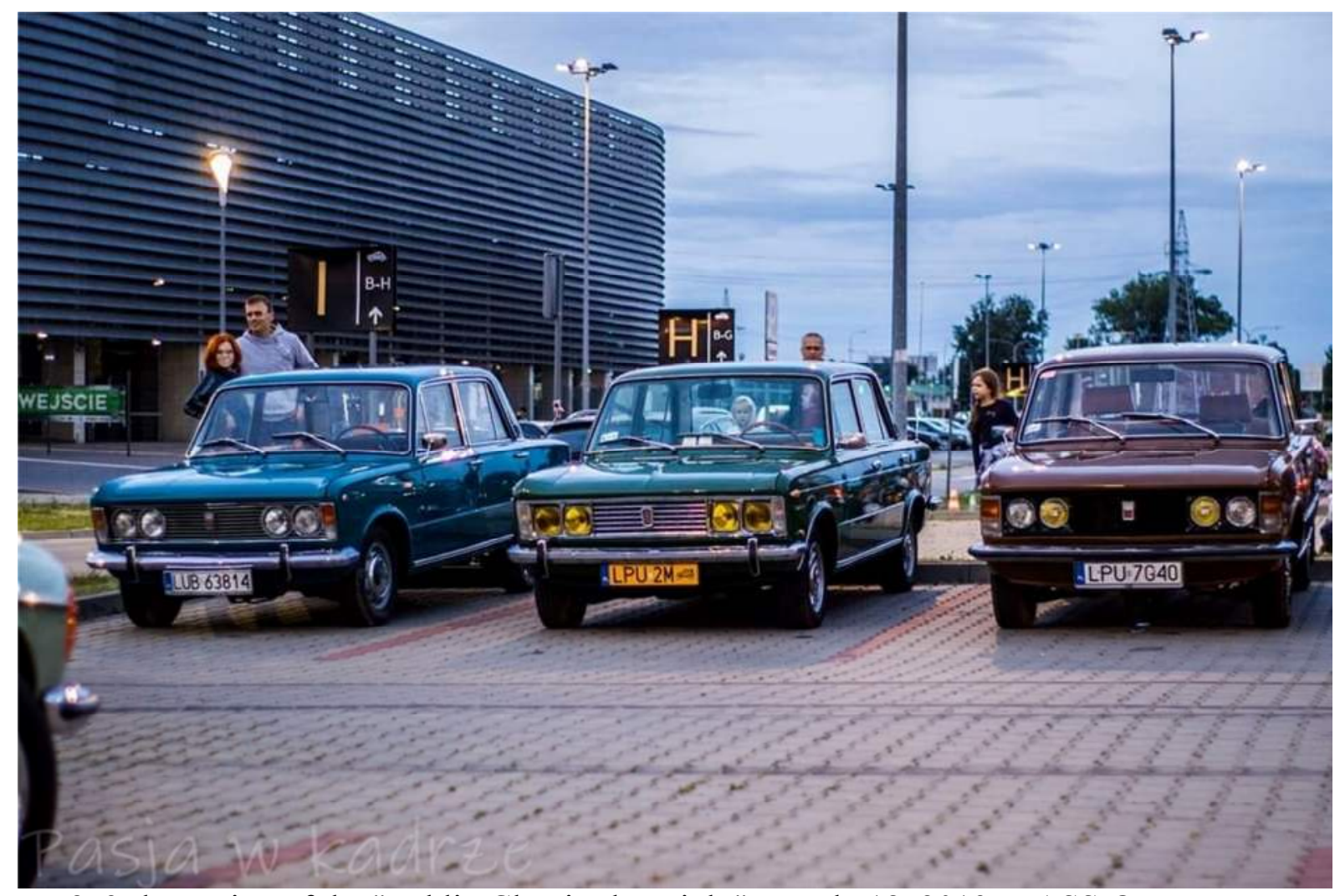

3. 3rd Meeting of the "Lublin Classics by Night" on July 18, 2019 - PASSION IN THE FRAME (author of the photos).

In this context, one should read the reservations previously made related to the activities undertaken by the expert, which, even performed in accordance with art and experience, do not guarantee a positive decision. In addition, in the event of making any mistakes, which can be removed by supplementing formal defects, the authority may issue a negative decision based on the so-called insufficient uniqueness of a given model [41].

Apart from the above-mentioned doubts regarding the participation of an expert in completing the white card, this activity is exaggerated in terms of formalism in determining the requirement to submit an application on a specific template and the method of its completion. It is the writing of a white card and an application for entry in the register of monuments that are the most important part of the entire procedure. The substantive correctness of the card and its formal requirements may determine the entry, and thus the transition to the next stages and final registration as a historic vehicle. The controversy is aroused by its outdated design, with a less indicative way of filling the boxes. The requirement relating to the basis weight of the paper and the inability to copy this document also seems bizarre. The ideal solution to this problem in the 21 st century would be the electronic version, composed of two parts, but structured in a simple and intuitive way so that the average user of websites could fill it in. After logging on to a platform specially created 
for this purpose, in the first part, the applicant would have to fill in the fields containing specific, technical vehicle data. In the second, however, there would be an open part describing the distinguishing features of a given item. The document filled in this way, after the option to save, should be sent to the Provincial Conservator of Monuments.

The consequence of the entry in the register is the obligation of its owner to carry out a technical examination. Art. $81 \mathrm{sec} .16$ of the Road Traffic Act indicates that the Minister responsible for transport issues, by way of regulation, determines the scope and manner of carrying out the tests and the templates of the documents submitted. Thus, in the appendices to the Ordinance issued by the Minister of Transport, Construction and Water Management of February 27, 2013 [42] you can find: an application for testing compliance with the technical conditions of a historic vehicle, a technical condition assessment protocol and a certificate of the test compliance with the technical conditions of a historic vehicle. The legislator also divided the technical tests into periodic tests, additional tests, and tests confirming the technical condition of the vehicle (Article 81 (2) of the Road Traffic Law) and specified the stations that can carry out technical tests of a vintage car, clearly indicating in Art. 83 sec. 1 point 2 letter $\mathrm{c}$ to regional vehicle inspection stations. These have broader powers and are equipped differently. They can carry out technical tests on all types of vehicles, regardless of their weight.

The examination of a historic vehicle differs from the procedures performed on other cars, as it consists not only in checking the functionality but also in checking the actual condition with the data included in the examination application. The application for examination of compliance with the technical conditions of a historic vehicle contains 10 main sections, broken down into smaller boxes with a detailed description. The content of the document submitted by the applicant, i.e. the owner, must be consistent with the facts, which is verified by an authorized diagnostician. During the test, the functioning of the individual units and mechanisms of the vehicle is checked, which guarantee the appropriate level of safety. After checking the application and after completing the activities related to the examination, the diagnostician prepares a "historical car technical condition assessment protocol", which includes: vehicle identification data, comparative assessment of the technical condition in relation to the requirements specified in the provisions on the technical conditions of vehicles and their necessary scope equipment, as well as the proposed restrictions on the manner of its use. In the end, the diagnostician issues a certificate of the conducted examination as to the compliance with the technical conditions of the vintage vehicle, allowing it or not to drive it as such.

Correctly performed technical inspection obligation significantly contributes to road safety. After all, a car operating on the basis of old technical solutions and safety standards is allowed for road traffic. Therefore, it should be remembered that the technical condition of a vehicle with older design solutions must not differ from the road safety standards. There is no doubt that it should be checked precisely - i.e. whether the mechanisms function in accordance with the assumptions at the time of their production. The validity of the technical inspection is indefinite (except for cars intended for commercial passenger transport). A diagnostician takes responsibility for its correctness "forever". In other words, it guarantees that the vehicle will be safe according to its specific standards until the end of its use. The entities authorized to conduct inspections specified by the legislator, indicating district vehicle inspection stations, should be positively assessed. They have special powers, thanks to which they can carry out tests on all types of vehicles. They are equipped with specialized equipment, and it should be assumed that the employees they employ have more professional experience. On the other hand, the excessive formalism of the content of the application for the examination as to the compliance with the technical conditions of the historic vehicle, 
which seems to be quite complicated for the owner drawing the application, does not deserve approval. The protocol, on the other hand, clearly confirms the data resulting from the application, and the certificate allows the vehicle to operate but does not specify what conditions should be met for it to be able to move on public roads. There is also a problem with the amount of fees for the examination, which seems to have been omitted by the legislator. These fees are usually higher than the fees for testing non-commercial vehicles, which the stations explain with more work and the indefinite duration of the research.

In addition, it should be noted that, unlike the normal vehicle testing procedure, the procedure for admitting a historic vehicle to traffic is formalized by the requirement to submit an application, and the diagnostician prepares a protocol during the test and issues a relevant certificate on its basis. Successful completion of the technical examination of a historic vehicle enables the commencement of the registration procedure for this vehicle in the communication department. The registration procedure begins with the submission of an application pursuant to Art. $63 \S 2$ of the CAP and the authority competent to accept it is the starosty depending on the applicant's place of residence. The registration application does not differ in this case from the one submitted when registering a non-commercial vehicle. Therefore, Art. 72 of the road traffic law, according to which an integral part of the application is, among others: proof of vehicle ownership, vehicle card, if issued, registration plates and registration certificate if the vehicle was registered. In the case of registration of a historic vehicle, an attachment to the application is a decision on entering the vehicle in the register of monuments or a document confirming the inclusion of the vehicle in the provincial register of monuments or confirming that the vehicle has been entered in the inventory of museum exhibits and a certificate from the examination of the historic vehicle, as to compliance with the technical conditions with a protocol technical condition assessment $(\S 2$ section 7 Regulation of the Minister of Infrastructure and Construction on the registration and marking of vehicles and the requirements for registration plates of 11 December 2017 [43]). The indicated attachments are submitted in original or copies certified by a notary, and sometimes the authentication of the attachments is made when submitting applications. Authentication may also be made by the district head on the basis of the submitted originals. According to Art. $72 \mathrm{sec}$. 2b of the Road Traffic Act, the lack of a registration certificate does not constitute an obstacle to vehicle registration, as the owner may submit a declaration of its absence under pain of criminal liability for false statements.

At the time of vehicle registration, the owner receives a temporary permit to travel on public roads, not exceeding 30 days (Article 74 (3) of the Road Traffic Act). After the deadline for temporary registration, such a permit and registration plates are returned to the authority that issued them, except in the case of the vehicle being exported abroad (Article 74 (5) of the Act - Road Traffic Law).

When losing a temporary permit, the vehicle simultaneously receives an official annotation in the registration certificate specifying the historic character of the vehicle [44]. An additional distinguishing feature compared to an ordinary vehicle is the receipt of special yellow number plates with black numbers, letters and the symbol of a vintage vehicle. As a result, the historic vehicle seems to be clearly marked, which is information for other road users. The exact appearance of the registration plates is specified in $\S 18$ para. 5 of the Regulation of the Minister of Infrastructure of July 22, 2002 on vehicle registration and marking (Journal of Laws of 2016, item 1038).

The registration costs of a historic vehicle are slightly higher than for a regular vehicle. Only the issue of license plates is decisive for the higher cost. The individual costs are presented as follows: issuance of a registration certificate - PLN 54.00, control sticker PLN 18.50, temporary permit ex officio - PLN 13.50, issue of registration plates - PLN 
100.00 (in the case of an ordinary car - PLN 80 PLN, 00), a set of legalization stickers for registration plates - PLN 12.50 and a registration fee of PLN 2.00. The total cost in the communications department is PLN 200.50 [45].

The registration procedure, although it has significant similarities to registering an ordinary vehicle, contains, in my opinion, quite important differences, in particular, it should be noted that there is no obligation to submit the current registration certificate. It should be mentioned that we are dealing with a historic vehicle and it is often impossible to find documents related to its previous owners, including the registration certificate. The owner must submit the same application, but with additional documents confirming the historic character of his vehicle. The lack of the obligation to present the registration certificate is very beneficial because sometimes the ID card was lost during the war and it is impossible to find it. The procedure ends with issuing a registration certificate along with the so-called yellow registration plates which distinguish a historic vehicle. However, the higher fee for the issue of license plates is completely incomprehensible. To sum up, the registration of a historic vehicle seems overly formalized and costly. It must be remembered that owners of historic vehicles usually incur high costs in restoring the vehicle to its proper technical condition, contributing to the expansion of the historic resources of Poland. Therefore, charging them with higher administrative fees than owners of ordinary vehicles is incomprehensible in the context of the principle of equality before the law.

\section{Conclusion}

The fashion for vintage vehicles in Poland is constantly growing. More and more people are willing to try to keep these timeless mementos of the past. The market is developing, more and more places where you can buy and repair such a vehicle. The car, apart from being used as a transport, becomes, on the one hand, a "toy" for pursuing a hobby, and, on the other, a good capital investment. Owning a historic vehicle is associated with various problems, also those set by law. Unfortunately, the legislator did not avoid mistakes in this field as well. Therefore, owners of vehicles eligible for historic registration often have a dilemma whether to go through this time-consuming, tedious, and expensive procedure. Moreover, it is impossible not to notice that legal regulations also have other consequences. Hence, "yellow plates" can be both the crowning achievement of efforts related to the reconstruction of the vehicle, but also can be perceived as an unnecessary distinguishing factor limiting the possibilities of its disposal.

The problem areas presented above in the article allow for the construction of several conclusions and demands for the legislator.

First of all, in Poland, there are undoubtedly many ways to buy a historic vehicle. The most popular are internet advertisements, advertisements in specialized press magazines, vehicle rallies and exhibitions, and historic exchanges. The least popular way is the purchase through an auction house, an entrepreneur importing cars from abroad, and purchase in special car dealerships. When buying, consider other considerations than when buying a regular car.

Secondly, the Polish law on historic vehicles does not allow for a precise definition of a historic vehicle. No less a legal obstacle is a not entirely clear requirement to obtain $75 \%$ of the vehicle's originality. The voivodship conservator of monuments assesses the fulfillment of this requirement on the basis of his own calculations. This status may be revoked in the event of a loss of historical, artistic, or scientific value of the vehicle, resulting in a value below $75 \%$ of its originality. Therefore, when making any modifications, even while exercising the utmost care to comply with the said requirement, one cannot be sure that this indicator will be maintained. On the other hand, however, the legislator did not provide for the control of such 
a vehicle, which makes this rule equivalent to the notion of "lex imperfecta". It should also be noted that historic vehicles do not have to meet technical requirements in order to be able to travel on public roads. Finally, owners of historic vehicles have the privilege of concluding a third party liability insurance contract for a period shorter than 12 months, but not shorter than 30 days.

Third, the legislator failed to properly regulate the issue of operation for business purposes. Although it allowed for occasional transport with historic vehicles structurally equipped with 7 or more seats, it did not attempt to raise the same precise amount for owners of vehicles with fewer seats.

Another important conclusion that emerges from the legal regulations introduced by the legislator should be related to the possibility of taking a car abroad, requiring a permit. The rationing introduced seems to be too restrictive and detailed. In the case of a sale, if the vehicle is a means of transport which is more than 50 years old and the value of which is higher than PLN 32,000.00, and at the same time is not entered in the register of monuments or museum objects, it is required to obtain a one-time permit for permanent export abroad. If the car is less than 50 years old and its value is less than PLN 32,000.00 and it is entered only in the register of monuments, then it is not necessary to obtain a permit. In special cases, the export license is issued by the competent Minister, and its premise is the highly vague and judged circumstance that the vehicle is assigned the characteristics of a monument of special value for the national heritage. At the same time, the legislator created a privilege resulting from Poland's membership of the European Union, which means that it is not necessary to obtain a license to export vehicles imported from the territory of the EU to Poland for a period not longer than 3 years, provided that the export is made to these countries.

A special type of permit is a temporary permit, valid for 3 years from the date of issue. The owner of a historic vehicle must apply for it if he intends to participate in the exhibition or there is a need to carry out conservation works outside Poland. A certain convenience for the vehicle owner is the permission to repeatedly export a historic vehicle abroad, if the owner proves that he regularly participates in exhibitions. This permit is also valid for 3 years.

Certainly, the legislator, introducing rationing through such restrictive instruments as export licenses, had to find a compromise between the right to property and the protection of national heritage. Such restrictive standards limit the rights of the owner, but on the other hand, they are aimed at full protection of the monument, keeping it in Polish resources.

Fundamental remarks can also be directed to the procedure for registering a historic vehicle, where the regulations relating to the expert opinion raise doubts. As a rule, this opinion is optional (only obligatory in three cases). The appraiser determines the historic value of the vehicle and prepares detailed photographic documentation, which is helpful in the next stages but does not guarantee the entry. It also seems problematic to determine the cost of this service, as there is no clearly established price list by the legislator.

Archaic, however, seem to be methods of filling the so-called white card. The stage of filling in the white card is the most important of the entire procedure. In the context of the rules resulting from the administrative procedure, especially Art. 63 of the Code of Administrative Procedure, the rules relating to the method of filling in the card are characterized by unnecessary formalism and at the same time referring to archaic methods of filling in documents. The formalism related to the requirements relating to the type of paper on which the card can be printed correlates with the requirements relating to its content. The degree of complexity and precision of the content somehow forces the use of assistance in its completion by people with specialist knowledge.

According to Art. $64 \S 2$ of the CAP, e.g. the use of paper of a different grammage may be considered as a formal failure of the application, and the applicant will be requested to 
complete it. In the event of failure to comply with this instruction, the application will not be considered.

Doubts arise when the card is completed by an expert. The regulations do not provide grounds for considering the expert to prepare an expert opinion/professional evaluation at the time of submitting the application, therefore only the owner/applicant is responsible for the final shape of the application. However, this fact can be assessed in the entirety of the evidence, i.e. through the prism of the fact that a possible negative decision must take into account the fact that the characteristics of the vehicle were prepared by a person who has specialist knowledge and experience. On the basis of the rules of evidence procedure contained in the CAP and the conditions for obtaining an entry, a refusal decision may only be dictated by the failure to meet any of the registration conditions, and the reasons for this refusal should be thoroughly justified. In particular, the authority should precisely explain how it understands in this particular proceeding the fuzzy terms that have occurred. The exact justification is all the more a requirement that determines the correctness of the decision when the author of the entries in the white card is an expert whose description is questioned by the conservator.

The vehicle is entered in the register if the conditions set out in the act on monuments are met. In addition, the provisions allow the authority to introduce elements of discretion in the decision. The concept of uniqueness used in the act is imprecise. Recognizing the car as unique should be sufficient to obtain the entry. Meanwhile, a kind of custom has developed to additionally evaluate this concept by the low or high uniqueness of the vehicle. In this way, the registration authority creates an additional field to assess the actual state of affairs as preventing the registration of the vehicle. It seems to be a "contra legem" action and constitutes the basis for an effective appeal application or even a motion for annulment of the decision due to a gross violation of the law. The regulation that allows for the re-registration of a deregistered vehicle located in a scrap yard should be assessed positively, as long as it has the characteristics of a historic vehicle.

No less important conclusion seems to be that the legislator rightly indicated separate rules for admitting a historic vehicle to traffic. Vehicles operating on the basis of old technical solutions and safety standards are allowed for road traffic. However, they must first pass a technical examination. These can only be carried out at regional vehicle inspection stations. The diagnosis begins with the submission of an application for examination of compliance with the technical conditions of the historic vehicle. Then, the diagnostician prepares a protocol confirming the data resulting from the application, and finally issues a certificate allowing or not the vehicle to be used on public roads. The diagnostician is obliged to carry out the examination diligently because it is a lifetime test (except for cars intended for commercial passenger transport). The main problem of this issue is the issue of the number of fees for such a service, which is not strictly defined, and which seems to be highly discretionary.

In conclusion, the registration of a historic vehicle at the department of transport is similar to the registration of an ordinary vehicle. The lack of a registration certificate does not constitute an obstacle to the registration of the vehicle, as the owner may submit a declaration of its absence under pain of criminal liability for false statements. After submitting the necessary documentation, the owner receives a new registration certificate with an official annotation specifying the historic character of the vehicle. Although this procedure is largely similar to the registration of an ordinary vehicle, its higher cost seems incomprehensible. 


\section{Source materials}

[1] https://motopodprad.pl/moda-na-oldtimery-i-youngtimery-klasyka-wraca-do-lask/ dostęp na 28.11.2019 r. [1].

[2] http://biznes.interia.pl/finanse-osobiste/news/popularne-staly-sie-inwestycje-w-dzielasztuki-alkohole-czy,2570940,4141 dostęp na 28.11.2019 r. [2].

[3] http://bezale.pl/2017/12/11/jakie-sa-sposoby-na-alternatywne-inwestycje/ dostęp na 28.11.2019 r. [3].

[4] http://www.motoweteranbazar.com/ dostęp na 28.11.2019 r. [5].

[5] https://www.ardorauctions.pl/ dostęp na 28.11.2019 r. [6].

[6] https://www.pzm.pl/pliki/zg/zabytki/fiva/miedzyna_kodeks_techniczny_fiva_2011.pdf dostęp na 28.11.2019 r. [9].

[7] http://www.infor.pl/prawo/powiat/rejestracja-samochodu/760608,Rejestracjazabytkowego-pojazdu-20172018-r.html dostęp na 28.11.2019 r. [16].

[8] http://wosoz.bip.mbnet.pl/zasady-dzialania/rejestracja-pojazdow-zabytkowych dostęp na 28.11.2019 r. [21].

[9] https://www.compensa.pl/ubezpieczenie/oc-motoklasyki/ dostęp na 28.11.2019 r. [30].

[10] http://www.motonews.pl/ubezpieczenia/ubezpieczenie-ac-dla-auta-zabytkowego.html dostęp na 28.11.2019 r. [31].

[11] https://www.nid.pl/pl/Dla_specjalistow/Badania_i_dokumentacja/zabytki_techniki/ dostęp na 28.11.2019 r. [38].

[12] https://www.nid.pl/upload/iblock/ce7/ce7a937130cce9d5c2699f458c103f9b.pdf dostęp na 28.11.2019 r. [37].

[13] Idzior M., Analiza rynku pojazdów zabytkowych w Polsce, Prace Naukowe Politechniki Warszawskiej, Marzec 2016, str. 141. [15].

[14] Jarosz - Żukowska S., Gwarancja ochrony własności i innych praw majątkowych, Uniwersytet Wrocławski, Wydział Prawa, Administracji i Ekonomii, str. 141. http://www.repozytorium.uni.wroc.pl/Content/53675/29_Sylwia_Jarosz_Zukowska.pdf [34].

[15] Konstytucja Rzeczypospolitej Polskiej z dnia 2 kwietnia 1997 r., Dz. U. z 1997 r. nr 78 , poz. 483. [33].

[16] Motor, Poradnik kupujacego. Używane Youngtimery i auta klasyczne, nr 3/2017, str. 3, 109, 110, 111, 113 [4], [7], [18], [22], [26]. [41].

[17] Puzio A., Samochody zabytkowe $i$ ich rejestracja - ile to kosztuje $i$ co daje? http://www.motofakty.pl/artykul/samochody-zabytkowe-i-ich-rejestracja-ile-tokosztuje-i-co-daje.html 17.04.2014 r. [40].

[18] Rozporządzenie Ministra Infrastruktury w sprawie warunków technicznych pojazdów oraz zakresu ich niezbędnego wyposażenia z dnia 31 grudnia 2002 r., Dz. U. 2003 nr 32 poz. 262. [24].

[19] Rozporządzenie Ministra Transportu, Budownictwa i Gospodarki Morskiej w sprawie homologacji sposobu montażu instalacji przystosowującej dany typ pojazdu do zasilania gazem z dnia 10 maja 2013 r., Dz. U, 2013 poz. 610. [25].

[20] Rozporządzenie Ministra Kultury i Dziedzictwa Narodowego w sprawie wywozu zabytków za granicę z dnia 18 kwietnia 2011 r., Dz. U. 2011 nr 89 poz. 510. [35].

[21] Rozporządzenie Ministra Transportu, Budownictwa i Gospodarki Morskiej w sprawie badań co do zgodności z warunkami technicznymi pojazdów zabytkowych z dnia 27 lutego 2013 r., Dz. U. 2013 poz. 337. [42].

[22] Rozporządzenie Ministra Infrastruktury w sprawie szczegółowych czynności organów związanych z dopuszczeniem pojazdu do ruchu oraz wzorów dokumentów w tych sprawach z dnia 27 września 2003 r., Dz. U. 2003 nr 192 poz. 1878. [44]. 
[23] Rozporządzenie Ministra Infrastruktury i Budownictwa w sprawie wysokości opłat za wydanie dowodu rejestracyjnego, pozwolenia czasowego, tablic (tablicy) rejestracyjnych i nalepki kontrolnej oraz ich wtórników z dnia 9 maja 2016 r., Dz. U. 2016 poz. 689. [45].

[24] Rozporządzenie Ministra Infrastruktury i Budownictwa w sprawie rejestracji i oznaczania pojazdów oraz wymagań dla tablic rejestracyjnych z dnia 11 grudnia 2017 r., Dz. U. 2017 poz. 1260 i 1926. [43].

[25] Rozporządzenie Ministra Kultury i Dziedzictwa Narodowego w sprawie prowadzenia rejestru zabytków, krajowej, wojewódzkiej i gminnej ewidencji zabytków oraz krajowego wykazu zabytków skradzionych lub wywiezionych za granicę niezgodnie z prawem z dnia 26 maja 2011 r., Dz. U. 2011 nr 113 poz. 661. [13], [20].

[26] Ustawa o ochronie zabytków i opiece nad zabytkami z dnia 23 lipca 2003 r., Dz. U. $2003 \mathrm{nr} 162$ poz. 1568. [8], [11].

[27] Ustawa Prawo o ruchu drogowym z dnia 20 czerwca 1997 r., Dz. U. 1997 Nr 98 poz. 602. [10], [23], [27].

[28] Ustawa o muzeach z dnia 21 listopada 1996 r., Dz. U. 1997 nr 5 poz. 24. [12].

[29] Ustawa o ubezpieczeniach obowiązkowych, Ubezpieczeniowym Funduszu Gwarancyjnym i Polskim Biurze Ubezpieczycieli Komunikacyjnych z dnia 22 maja 2003 r., Dz. U. 2003 nr 124 poz. 1152. [14], [29].

[30] Ustawa o recyklingu pojazdów wycofanych z eksploatacji z dnia 20 stycznia 2005 r., Dz. U. 2005 nr 25 poz. 202. [28].

[31] Ustawa o transporcie drogowym z 6 września 2001 r., Dz. U. 2001 nr 125 poz. 1371. [32].

[32] Ustawa Kodeks postępowania administracyjnego z dnia 14 czerwca 1960 r., Dz. U. $1960 \mathrm{nr} 30$ poz. 168. [39].

[33] Woźniak E., Zarzadzanie amerykańskimi samochodami zabytkowymi na rynku polskim, Wydawnictwo Poligraf, Brzezia Łąka 2010. [17 - str. 7], [19 - str. 7], [36 - str. 87]. 